\title{
APLIKASI PENGENDALIAN ARM MANIPULATOR 4 DOF MENGGUNAKAN ALGORITMA FINITE STATE MACHINE SEBAGAI PEMINDAH SAYURAN PASCAPANEN TEROZONISASI
}

\author{
Muhamad Harun Jihad*), Trias Andromeda, and Sudjadi \\ Departemen Teknik Elektro, Universitas Diponegoro \\ Jl. Prof. Sudharto, SH, Kampus UNDIP Tembalang, Semarang 50275, Indonesia \\ ${ }^{*}$ E-mail : muhammadharunjihad@gmail.com
}

\begin{abstract}
Abstrak
Pada era global ini, pemanfaatan arm manipulator robot dalam dunia industri telah semakin luas. Diantaranya untuk keperluan pengganti manusia pada kondisi lingkungan yang berbahaya. Pemindahan barang oleh lengan robot sering digunakan karena tingkat presisinya yang tinggi untuk menyesuaikan keterbatasan ruang gerak yang ada dengan lingkungan yang tidak aman bagi manusia. Untuk itu diperlukan pengendalian pergerakan lengan robot yang sederhana untuk mengoptimalkan kondisi keterbatasan ruang dan lingkungan tersebut. Penelitian ini dilakukan dengan perancangan pengendalian robot arm manipulator dengan 4 derajat kebebasan (DOF). Untuk metode pengendalian lengan digunakan Finite State Machine dengan masukan berupa sudut dan keluaran berupa koordinat end effector lengan robot. Untuk unit pengontrolnya digunakan mikrokontroller ATMEGA328p dan menggunakan bahasa C. Dengan menggunakan algoritma Finite State Machine, robot lengan dapat mengikuti arahan perintah sudut untuk masing-masing joint dengan kinematika maju. Untuk posisi pemindahan barang mengalami error pada sumbu X sampai dengan $3,6 \mathrm{~cm}$, sumbu $Y$ sejauh $4,17 \mathrm{~cm}$ dan sumbu $Z$ sejauh $4,48 \mathrm{~cm}$.
\end{abstract}

Kata kunci : Arm Manipulator, Derajat Kebebasan, Finite State Machine, ATMega328p

\begin{abstract}
In this global era, robotic manipulator arm in the industrial world has become increasingly widespread used. Among them for the purpose of moving object in extreme environment. The movement of object by the robotic arm is often used because of the high level of precision to adjust the limitations of the available space with a extreme condition. For this reason, it is necessary to control the movement of the robot arm which is simple to optimize the conditions of the limited space and condition. This final project is carried out by controlling the robot arm manipulator with 4 degrees of freedom (DOF). For the arm control method used Finite State Machine with input in the form of angle and output in the form of coordinate end effector robot arm. The controller unit uses ATMEGA328p microcontroller and uses C language. By using the Finite State Machine algorithm, arm robots can follow the direction of the angular commands for each joint with advanced forward kinematics. The position of moving goods experienced an error in the $\mathrm{X}$ axis up to $3,6 \mathrm{~cm}$, $\mathrm{Y}$ axis up to $4,17 \mathrm{~cm}$ and the $\mathrm{Z}$ axis up to $4,48 \mathrm{~cm}$.
\end{abstract}

Keywords: Arm Manipulator, Degree of Freedom, Finite State Machine, ATMega328p

\section{Pendahuluan}

Pada era global ini, pemanfaatan lengan robot dalam dunia industri telah semakin luas. Diantaranya untuk keperluan memindahkan barang. Pemindahan barang oleh lengan robot sering digunakan karena tingkat presisi untuk menyesuaikan keterbatasan ruang gerak yang ada dengan lingkungan yang tidak aman bagi manusia. Struktur robot lengan terdiri atas mainframe yang disebut lengan (arm) dan pergelangan (wrist). Lengan tersusun atas serangkaian link, dimana link yang satu dengan link yang lainnya dihubungkan dengan joint.[1]

Penerapan algoritma Finite State Machine (FSM) terdiri dari serangkaian state yang menentukan keputusan. Setiap state dapat berpindah ke state lainnya jika memenuhi kondisi yang telah ditentukan sebelumnya.[2] Kinematika dalam robotik adalah suatu bentuk pernyataan yang berisi tentang deskripsi matematik geometri dari suatu struktur robot. Ozon merupakan zat desinfektan yang kuat, 
beberapa penelitian telah memperlihatkan bahwa hanya dengan konsentrasi yang rendah dari ozon (kurang dari 0,5 $\mathrm{mg} / \mathrm{liter}$ ) sudah dapat membunuh mikroorganisme dalam air, bahkan ozon juga dapat mensterilkan air. Konsentrasi ozon yang biasa digunakan untuk proses desinfeksi air ialah 0,5 - 0,4 mg/l. Konsentrasi ozon sebesar 0,02 mg/l dapat bersifat racun bagi Eschericia coli dan Streptococcus facealis. Ozon akan bereaksi dengan protoplasma sel dengan berperan sebagai oksidator[3].

Penelitian menghasilkan model kinematik lengan robot 4 DOF dengan metode Denavit-Hartenberg (DH) maupun metode kinematika balik. [4] Pada penelitian penulis ini akan merancang aplikasi penerapan FSM[5] pada lengan robot untuk perintah gerak dari lengan robot. Nilai dari pengukuran sudut akan dihitung dengan kinematika maju untuk menentukan posisi akhir dari end effector.

\section{Metode}

Perancangan sistem kendali pergerakan arm manipulator ini dibagi menjadi dua yaitu perancangan perangkat keras dan perancangan perangkat lunak pergerakan arm manipulator itu sendiri. Sistem perancangan perangkat arm manipulator secara umum dapat dilihat pada Gambar 1.

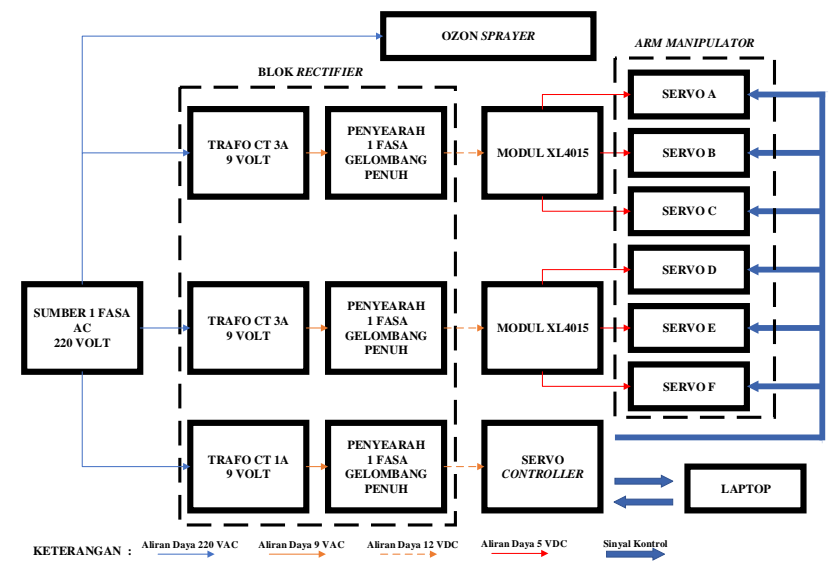

Gambar 1. Diagram Blok Perancangan Perangkat

\subsection{Perancangan Perangkat Keras}

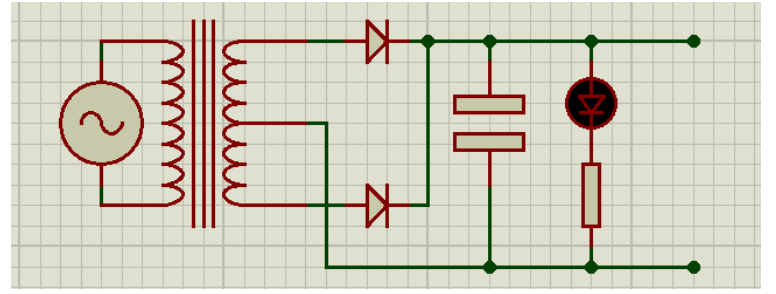

Gambar 2 Rangkaian catu daya servo

Penyearah yang digunakan untuk suplai rangkaian mikro adalah penyearah gelombang penuh dengan trafo center tap sebagai sumber daya. Pada penyearah gelombang penuh dengan center tap, digunakan trafo center tap dengan tapping tegangan keluaran yang digunakan $9 \mathrm{~V}$ dan $12 \mathrm{~V}$ dan memerlukan dua buah dioda untuk menyearahkan tegangan keluaran trafo serta kapasitor untuk mengurangi riak gelombang keluaran penyearah. Rangkaian penyearahan untuk suplai rangkaian mikro dapat dilihat pada Gambar 2.

Perancangan mekanik arm manipulator ini dirancang dengan menggunakan 4 derajat kebebasan yang berperan menggerakan end-effector (gripper) ke posisi tujuan. Aktuator pada tiap-tiap sendi arm manipulator menggunakan motor servo[6]. Spesifikasi pada robot arm manipulator dengan panjang link 1 (L1) $115 \mathrm{~mm}$, link 2 (L2) $105 \mathrm{~mm}$, link 3 (L3) $65 \mathrm{~mm}$, dan link 4 (L4) 165mm.

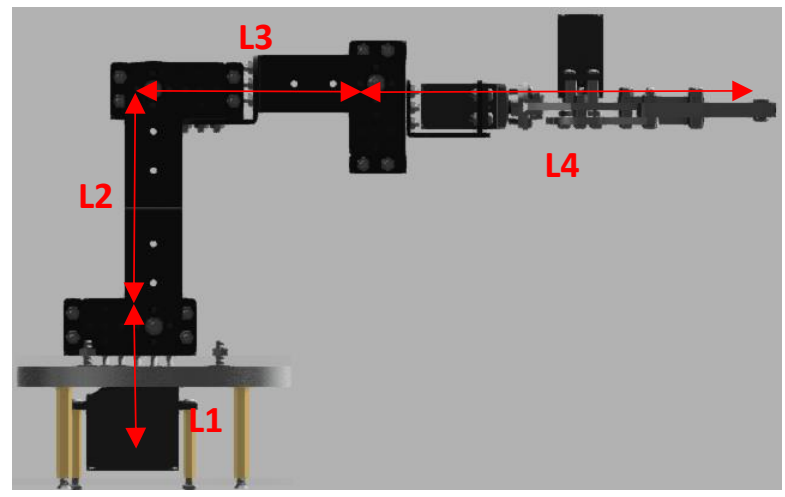

Gambar 3. Mekanik robot arm manipulator

\subsection{Perancangan Perangkat Lunak}

Metode gerak adalah metode bagaimana arm manipulator dalam menggerakan end effector ke posisi tertentu atau koordinat tertentu. Pada sistem kendali pergerakan arm manipulator ini, nilai dari titik yang akan dituju akan dihitung untuk memberikan sudut yang menggerakan servo dan mengarahkan end effector ke titik yang diinginkan.

Tabel 1. Nilai Parameter Denavit Hartenberg

\begin{tabular}{ccccc}
\hline Sendi & Sudut $\mathrm{a}_{\mathrm{i}}$ & Link $\mathrm{a}_{\mathrm{i}}$ & Link $\mathrm{d}_{\mathrm{i}}$ & Sudut $\theta_{\mathrm{i}}$ \\
\hline 1 & 90 & 1 & 115 & $\theta_{1}$ \\
2 & 0 & 105 & 0 & $\theta_{2}$ \\
3 & 0 & 65 & 0 & $\theta_{3}$ \\
4 & 0 & 165 & 0 & $\theta_{4}$ \\
5 & 90 & 0 & 0 & $\theta_{5}$ \\
\hline
\end{tabular}

Pembuatan matriks A dari setiap joint didapat dengan cara memberikan nilai dari tabel 1 menjadi masukan ke persamaan :

$A_{n}^{n-1}=\left[\begin{array}{cccc}\cos \theta_{n} & -\sin \theta_{n} \cos \alpha_{n} & \sin \theta_{n} \sin \alpha_{n} & l_{n} \cos \theta_{n} \\ \sin \theta_{n} & \cos \theta_{n} \cos \alpha_{n} & -\cos \theta_{n} \sin \alpha_{n} & l_{n} \sin \theta_{n} \\ 0 & \sin \alpha_{n} & \cos \alpha_{n} & d_{n} \\ 0 & 0 & 0 & 1\end{array}\right]$ 
Kemudian didapatkan matriks $T_{5}^{0}$ dengan mengalikan semua matrik tersebut berurutan sendi pertama ke akhir yang didalamnya terdapat matriks $R_{5}^{0}$ yang merupakan matriks orientasi dan $P_{5}^{0}$ yang merupakan matriks vektor posisi dari end effector.

$T_{5}^{0}=A_{1}^{0} \cdot A_{2}^{1} \cdot A_{3}^{2} \cdot A_{4}^{3} \cdot A_{5}^{4}$

$T_{5}^{0}=\left[\begin{array}{cc}R_{5}^{0} & P_{5}^{0} \\ 0 & 1\end{array}\right]$

$R_{5}^{0}=\left[\begin{array}{ccc}C_{1}\left(C_{2345}\right) & S_{1} & C_{1}\left(S_{2345}\right) \\ S_{1}\left(C_{2345}\right) & -C_{1} & S_{1}\left(S_{2345}\right) \\ S_{2345} & 0 & -C_{2345}\end{array}\right]$

$P_{5}^{0}=\left(\begin{array}{l}X \\ Y \\ Z\end{array}\right)$

$\left(\begin{array}{l}X \\ Y \\ Z\end{array}\right)=\left(\begin{array}{c}C_{1}\left[165 C_{234}+65 C_{23}+105 C_{2}+1\right] \\ S_{1}\left[165 C_{234}+65 C_{23}+105 C_{2}+1\right] \\ 165 S_{234}+65 S_{23}+105 S_{2}+115\end{array}\right)$

\subsection{Perancangan Perangkat Lunak}

Perancangan software mikrokontroler menggunakan bahasa pemrograman $\mathrm{C}$ dengan compiler Arduino IDE. Mikrokontroler Atmega328P[7] dirancang agar dapat mengontrol motor servo dan dapat saling berkomunikasi. Pada sisi arm manipulator bertugas sebagai penerima data dari komputer kemudian diolah ke sinyal motor servo.

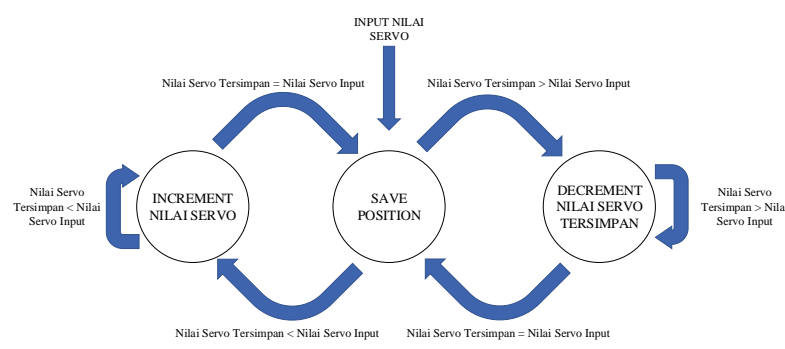

Gambar 4. Algoritma Finite State Machine

Algoritma FSM pada Gambar 4 yang diterapkan sebagai penentuan gerak servo untuk setiap nilai yang dibandingkan pada nilai servo yang tersimpan untuk tiap servo. Nilai pembanding berdasarkan nilai input melalui komunikasi serial untuk diteruskan ke posisi simpan sudut servo. Nilai servo akan diulang penjumlahan atau pengurangannya hingga mencapai titik nilai yang sama antara nilai tersimpan dengan masukan.

\section{Hasil dan Analisis}

3.1. Pengujian Perangkat Keras 3.1.1. Pengujian Rangkaian Daya

Rangkaian daya servo diuji dengan cara mengecek nilai tegangan dan arus pada servo ketika posisi diam dan posisi bergerak. Pengujian dilakukan untuk mengetahui kesesuaian nilai masukan tegangan serta arus kedalam mikro dalam kondisi diam dan bergerak dengan data yang tersedia.

Tabel 2. Pengujian tegangan rangkaian penyearah

\begin{tabular}{ccccc}
\hline NO & $\begin{array}{c}\text { CT 12V 5A } \\
\text { (A) }\end{array}$ & $\begin{array}{c}\text { RECT 5A } \\
\text { (B) }\end{array}$ & $\begin{array}{c}\text { CT 9V 3A } \\
\text { (C) }\end{array}$ & $\begin{array}{c}\text { RECT 3A } \\
\text { (D) }\end{array}$ \\
\hline 1 & 12,7 & 17,35 & 9,2 & 12,92 \\
2 & 12,5 & 17,41 & 9,3 & 12,97 \\
3 & 12,6 & 17,39 & 9,4 & 12,95 \\
4 & 12,8 & 17,46 & 9,2 & 12,94 \\
5 & 12,5 & 17,37 & 9,4 & 12,97 \\
Mean & 12,62 & 17,396 & 9,3 & 12,95 \\
\hline
\end{tabular}

Keluaran tegangan rata-rata berdasarkan tabel 2 pada trafo CT $12 \mathrm{~V} 5 \mathrm{~A}$ adalah $12,62 \mathrm{~V}$ dan pengukuran penyearah adalah $17,396 \mathrm{~V}$. Keluaran tegangan rata-rata pada trafo CT 9V 3A adalah 9,3 V dan pengukuran penyearah adalah $12,95 \mathrm{~V}$. Nilai keluaran dari setiap trafo penyearah cukup memenuhi nilai masuk ke rangkaian modul XL4015 sebagai penurun tegangan untuk suplai motor servo.

Tabel 3. Pengujian keluaran modul XL4015

\begin{tabular}{ccc}
\hline NO & $\begin{array}{c}\text { XL4015 } \\
(\mathrm{E})\end{array}$ & $\begin{array}{c}\mathrm{XL4015} \\
(\mathrm{F})\end{array}$ \\
\hline 1 & 6,01 & 6,01 \\
2 & 6,02 & 6,03 \\
3 & 6,01 & 6,02 \\
4 & 6,02 & 6,01 \\
5 & 6,02 & 6,01 \\
Rata-rata & 6,016 & 6,016 \\
\hline
\end{tabular}

Keluaran tegangan rata-rata berdasarkan tabel 3 pada modul XL4015[8] dari sumber penyearah trafo CT 5A adalah 6,016 V. Keluaran tegangan rata-rata pada modul XL4015 dari sumber penyearah trafo CT 3A adalah 6,016 $\mathrm{V}$. Nilai rata-rata tersebut telah memenuhi syarat tegangan kerja suplai motor servo sebesar $5 \mathrm{~V}$ sampai $7 \mathrm{~V}$.

Tabel 4. Pengujian arus rangkaian arm manipulator

\begin{tabular}{ccccccc}
\hline \multirow{2}{*}{ NO } & \multicolumn{6}{c}{ Arus (Ampere) } \\
\cline { 2 - 7 } & \multicolumn{7}{c}{ Keadaan Standby } & \multicolumn{3}{c}{ Keadaan Bergerak } \\
\cline { 2 - 7 } & $(\mathbf{H})$ & $(\mathbf{l})$ & $(\mathrm{J})$ & $(\mathrm{H})$ & $(\mathbf{l})$ & $(\mathrm{J})$ \\
\hline 1 & 0,17 & 0,15 & 0,85 & 1,5 & 1,2 & 4,4 \\
2 & 0,17 & 0,15 & 0,85 & 1,5 & 1,2 & 3,6 \\
3 & 0,17 & 0,15 & 0,85 & 1,5 & 1,2 & 3,92 \\
4 & 0,17 & 0,15 & 0,85 & 1,5 & 1,2 & 4,2 \\
5 & 0,17 & 0,15 & 0,85 & 1,5 & 1,2 & 4,4 \\
Mean & 0,17 & 0,15 & 0,85 & 1,5 & 1,2 & 4,104 \\
\hline
\end{tabular}


Berdasarkan tabel 4, keluaran arus rata-rata saat posisi end effector diam adalah $0,17 \mathrm{~A}$ pada titik $\mathrm{H}$ dan $0,15 \mathrm{~A}$ pada titik I dan 0,85 A pada titik J. Arus rata-rata pada saat end effector bergerak bernilai pada titik $\mathrm{H}$ adalah 1,5 A, pada titik I adalah 1,2 A, dan pada titik J adalah 4,104 A. Nilai tersebut telah cukup untuk disuplai oleh sumber dengan nilai trafo sebesar $8 \mathrm{~A}$.

\subsubsection{Pengujian Motor Servo}

Pengujian motor servo dilakukan untuk mengetahui respon motor servo terhadap masukan sudut yang diberikan. Motor servo TowerPro MG995, RDS3115 dan RDS3135 menggunakan sinyal PWM dengan lebar pulsa $0,5 \mathrm{~ms}$ sampai dengan 2,5 ms. Pengukuran dilakukan menggunakan busur derajat dengan ketelitian $1^{\circ}$. Lebar pulsa terendah $(0,5 \mathrm{~ms})$ sebagai acuan titik $0^{\circ}$. Lebar pulsa dinaikan sampai terdapat perubahan posisi gear dari motor servo. Hasil terdapat pada Gambar 5.

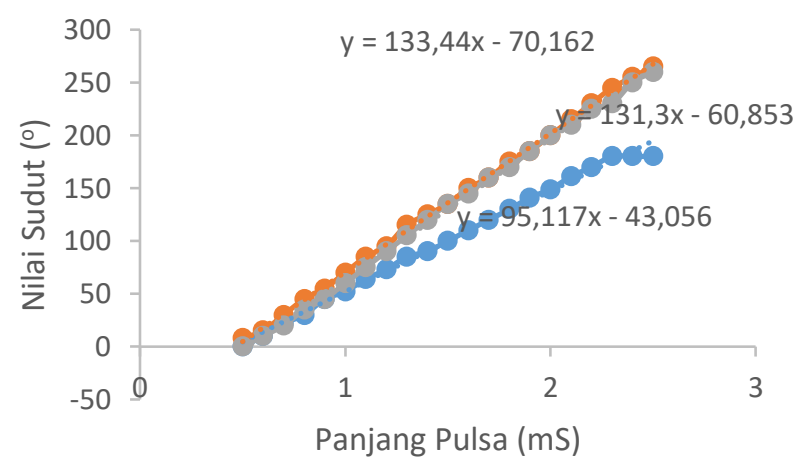

Gambar 5. Grafik Hubungan Lebar Pulsa dan Sudut Servo

Persamaan 1 menunjukkan resolusi dari motor servo Tower Pro MG995 sebesar $9,5117^{\circ}$ setiap $0,1 \mathrm{~ms}$. Persamaan 2 menunjukkan resolusi dari motor servo RDS3115 sebesar $13,13^{\circ}$ setiap 0,1 ms. Persamaan 3 menunjukkan resolusi dari motor servo RDS3135 sebesar $13,344^{\circ}$ setiap $0,1 \mathrm{~ms}$.

sudut $=95,117 *$ pulsa $-43,056$

sudut $=131,3 *$ pulsa $-60,853$

sudut $=133,44 *$ pulsa $-70,162$

\subsection{Pengujian Perangkat Lunak}

Pengujian perangkat lunak (software) dilakukan untuk menguji kemampuan dari proses pengolahan dan perhitungan data dalam menunjang proses pengontrolan robot arm manipulator pemindah barang.

\subsubsection{Pengujian Komunikasi Serial}

Pengujian komunikasi serial ini bertujuan untuk mengetahui kesesuaian data yang dikirim komputer dengan apa yang diterima mikrokontroler. Pengujian ini dilakukan dengan cara mengirimkan data kedalam mikrokontroler kemudian data tersebut dikirimkan kembali ke komputer untuk melihat kesesuaian data.

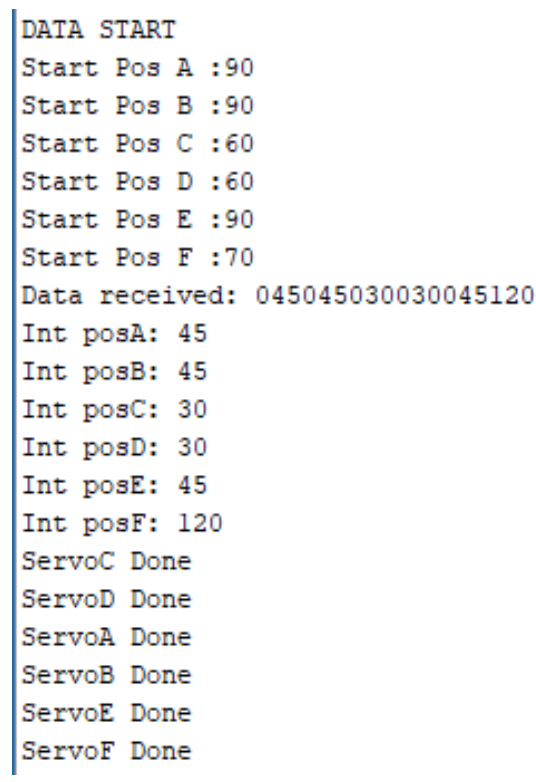

Gambar 6. Respon Komunikasi Mikrokontroler

Berdasarkan Gambar 6, dengan mengirimkan nilai data 045045030030045120 yang melambangkan bahwa untuk sudut servo A bernilai $45^{\circ}$, servo B bernilai $45^{\circ}$, servo C bernilai $30^{\circ}$, servo D bernilai $30^{\circ}$, servo E bernilai $45^{\circ}$, dan servo $\mathrm{F}$ bernilai $120^{\circ}$, mikrokontroler telah mengeksekusi perintah untuk mengirimkan semua sinyal kontrol menuju servo. Hal ini telah sesuai dengan program yang dibuat.

\subsubsection{Pengujian Keluaran Sinyal PWM}

Pengujian keluaran sinyal PWM dilakukan untuk mengetahui lebar pulsa yang dihasilkan oleh mikrokontroler. Pembangkitan sinyal PWM menggunakan timer pada mikrokontroler. Nilai servo merupakan nilai PWM yang dibuat oleh timer mikrokontroler. Sinyal PWM yang dihasilkan mikrokontroler diukur menggunakan osiloskop. Berdasarkan Gambar 7, rata - rata error lebar pulsa yang terjadi sebesar $0,007 \mathrm{~ms}$. Rata - rata error duty cycle yang terjadi sebesar $0,02 \%$.

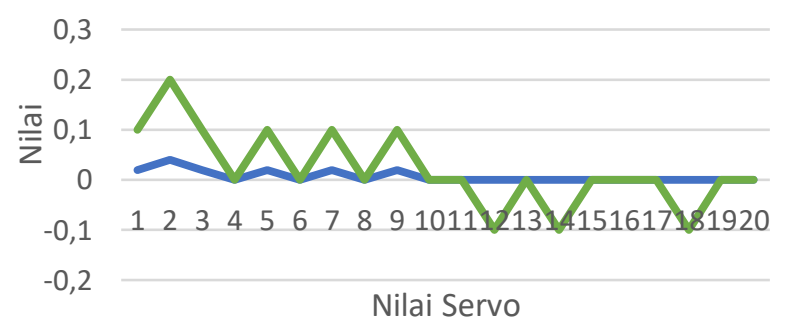

Gambar 7. Grafik Error Lebar Pulsa dan Duty Cycle Terukur - Terhitung 


\subsection{Pengujian Pergerakan Sistem}

\subsubsection{Pengujian Pengambilan Posisi 1}

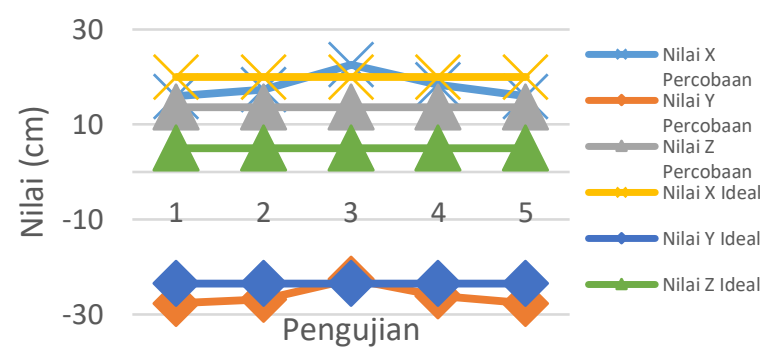

Gambar 8. Grafik Perbandingan Pengambilan Posisi 1

Berdasarkan Gambar 8, rata - rata error pada pengambilan posisi 1 sebesar $X=2,99 \mathrm{~cm}, Y=-3,02 \mathrm{~cm}$ dan $Z=8,6296$ $\mathrm{cm}$. Error $X$ dan $Y$ terbesar terjadi pada pengujian ke-1 dan ke-5 dengan nilai error $X=4,045 \mathrm{~cm}$ dan $Y=-4,134 \mathrm{~cm}$. Error $\mathrm{Z}$ terbesar terjadi pada pengujian keseluruhan dengan nilai error $8,6296 \mathrm{~cm}$.

\subsubsection{Pengujian Pengambilan Posisi 2}

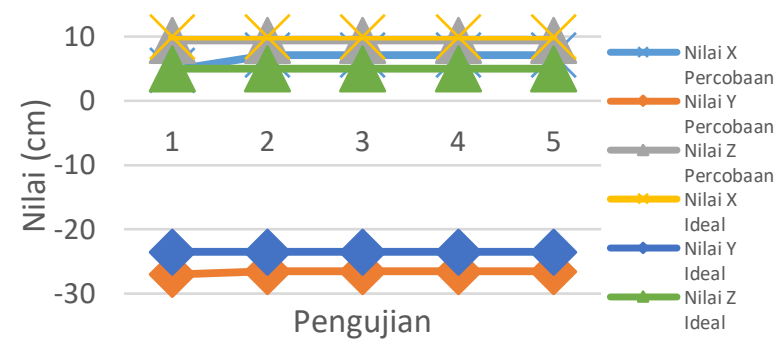

Gambar 9. Grafik Perbandingan Pengambilan Posisi 2

Berdasarkan Gambar 9, rata - rata error pada pengambilan posisi 2 sebesar $\mathrm{X}=3,36 \mathrm{~cm}, \mathrm{Y}=-3,13 \mathrm{~cm}$ dan $\mathrm{Z}=4,394$ $\mathrm{cm}$. Error $X$ terbesar terjadi pada pengujian ke-1 dengan nilai error $X=5,23 \mathrm{~cm}$. Error $X$ terbesar terjadi pada pengujian ke-1 dengan nilai error $\mathrm{Y}=-3,54 \mathrm{~cm}$. Error $\mathrm{Z}$ terbesar terjadi pada pengujian keseluruhan dengan nilai error $4,394 \mathrm{~cm}$.

\subsubsection{Pengujian Pengambilan Posisi 3}

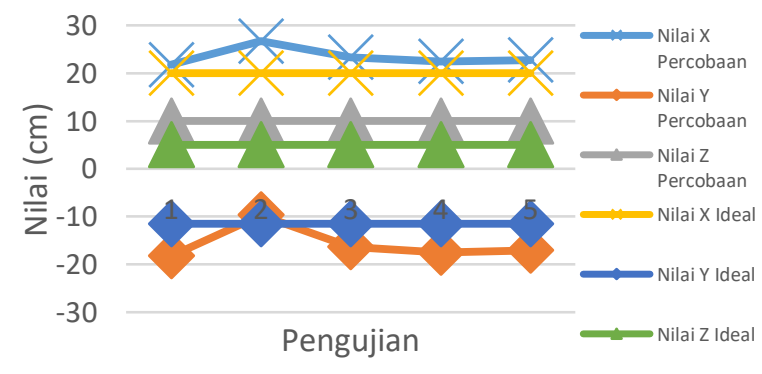

Gambar 10. Grafik Perbandingan Pengambilan Posisi 3
Berdasarkan Gambar 10, rata - rata error pada pengambilan posisi 3 sebesar $X=3,36 \mathrm{~cm}, Y=-4,99 \mathrm{~cm}$ dan $Z=5,006 \mathrm{~cm}$. Error $X$ terbesar terjadi pada pengujian ke-2 dengan nilai error $6,7 \mathrm{~cm}$. Error $Y$ terbesar terjadi pada pengujian ke-1 dengan nilai error $-6,7 \mathrm{~cm}$. Error $\mathrm{Z}$ terbesar terjadi pada pengujian keseluruhan dengan nilai error $5,006 \mathrm{~cm}$.

\subsubsection{Pengujian Pengambilan Posisi 4}

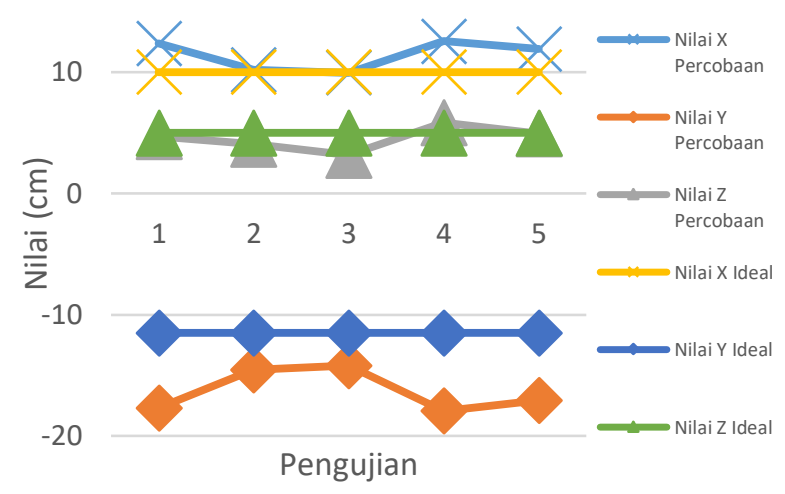

Gambar 11. Grafik Perbandingan Pengambilan Posisi 4

Berdasarkan Gambar 11, rata - rata error pada pengambilan posisi 4 sebesar $X=1,425 \mathrm{~cm}, Y=-4,782 \mathrm{~cm}$ dan $Z=0,7978 \mathrm{~cm}$. Error $X$ dan $Y$ terbesar terjadi pada pengujian ke-4 dengan nilai error berurutan 2,5679 $\mathrm{cm}$ dan $-6,4488 \mathrm{~cm}$. Error $\mathrm{Z}$ terbesar terjadi pada pengujian ke-3 dengan nilai error $1,8355 \mathrm{~cm}$.

\subsubsection{Pengujian Pengambilan Posisi 5}

Berdasarkan Gambar 12, rata - rata error pada pengambilan posisi 5 sebesar $X=5,876 \mathrm{~cm}, Y=0 \mathrm{~cm}$ dan $\mathrm{Z}=1,2585 \mathrm{~cm}$. Error $\mathrm{X}$ terbesar terjadi pada pengujian ke4 dengan nilai error $6,4429 \mathrm{~cm}$. Error $Z$ terbesar terjadi pada pengujian ke-3 dengan nilai error $2,7783 \mathrm{~cm}$. Nilai Y tidak terdapat error karena sudah mencapai titik ideal pada setiap pengujian.

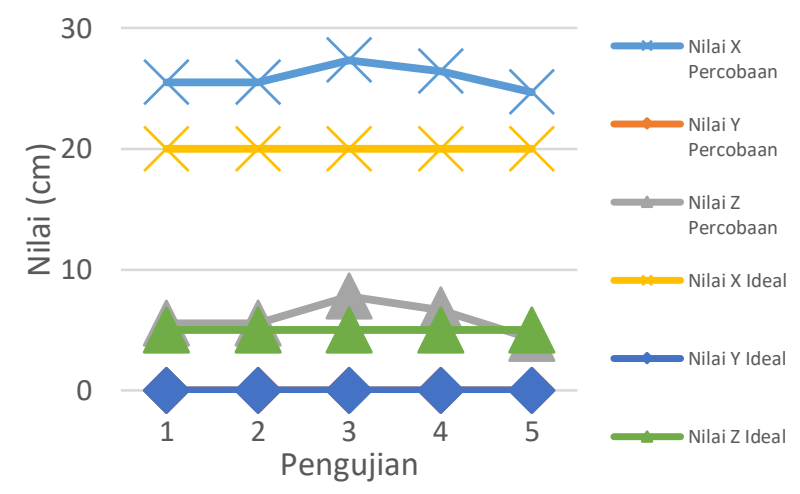

Gambar 12. Grafik Perbandingan Pengambilan Posisi 5 


\subsubsection{Pengujian Pengambilan Posisi 6}

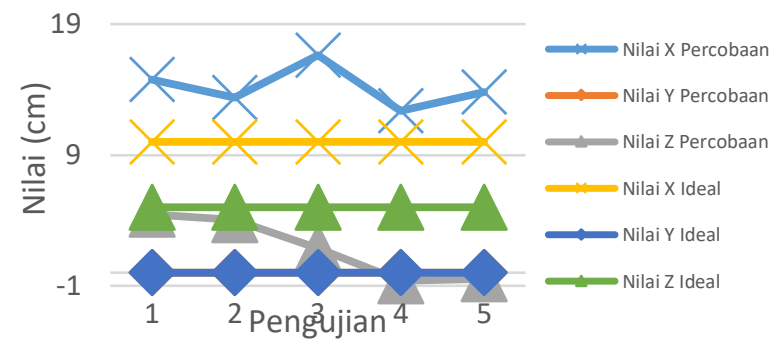

Gambar 13. Grafik Perbandingan Pengambilan Posisi 6

Berdasarkan Gambar 13, rata - rata error pada pengambilan posisi 6 sebesar $X=4,18 \mathrm{~cm}, Y=0 \mathrm{~cm}$ dan $\mathrm{Z}=3,1562 \mathrm{~cm}$. Error $\mathrm{X}$ terbesar terjadi pada pengujian ke3 dengan nilai error $6,6225 \mathrm{~cm}$. Error $\mathrm{Z}$ terbesar terjadi pada pengujian ke-4 dengan nilai error $5,4856 \mathrm{~cm}$. Nilai Y tidak terdapat error karena sudah mencapai titik ideal pada setiap pengujian.

\subsubsection{Pengujian Pengambilan Posisi 7}

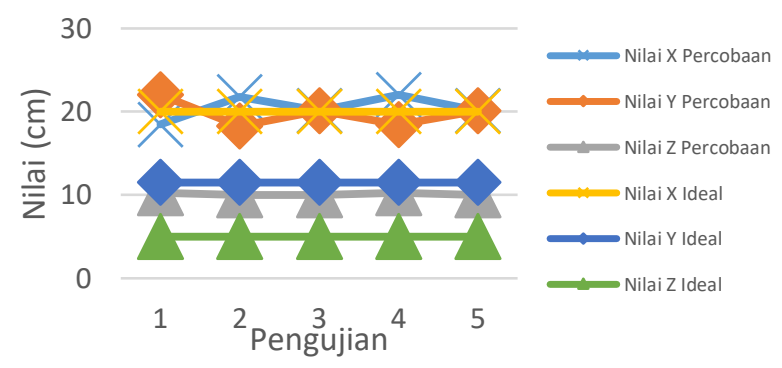

Gambar 14. Grafik Perbandingan Pengambilan Posisi 7

Berdasarkan Gambar 14, rata - rata error pada pengambilan posisi 7 sebesar $X=1,1 \mathrm{~cm}, Y=8,29 \mathrm{~cm}$ dan $\mathrm{Z}=5,11 \mathrm{~cm}$. Error $\mathrm{X}$ terbesar terjadi pada pengujian ke-4 dengan nilai error 2,0293 cm. Error Y terbesar terjadi pada pengujian ke-1 dengan nilai error $10,529 \mathrm{~cm}$. Error $\mathrm{Z}$ terbesar terjadi pada pengujian ke- 1 dan ke-4 dengan nilai error $5,2691 \mathrm{~cm}$.

\subsubsection{Pengujian Pengambilan Posisi 8}

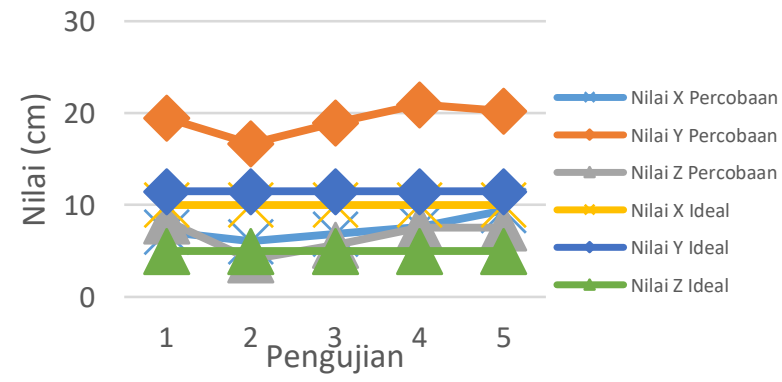

Gambar 15. Grafik Perbandingan Pengambilan Posisi 8
Berdasarkan Gambar 15, rata - rata error pada pengambilan posisi 8 sebesar $X=2,578 \mathrm{~cm}, Y=7,756 \mathrm{~cm}$ dan $Z=1,994 \mathrm{~cm}$. Error $X$ terbesar terjadi pada pengujian ke-2 dengan nilai error 3,9318 cm. Error Y terbesar terjadi pada pengujian ke-4 dengan nilai error 9,444 cm. Error Z terbesar terjadi pada pengujian ke-1 dengan nilai error $3,2926 \mathrm{~cm}$.

\subsubsection{Pengujian Pengambilan Posisi 9}

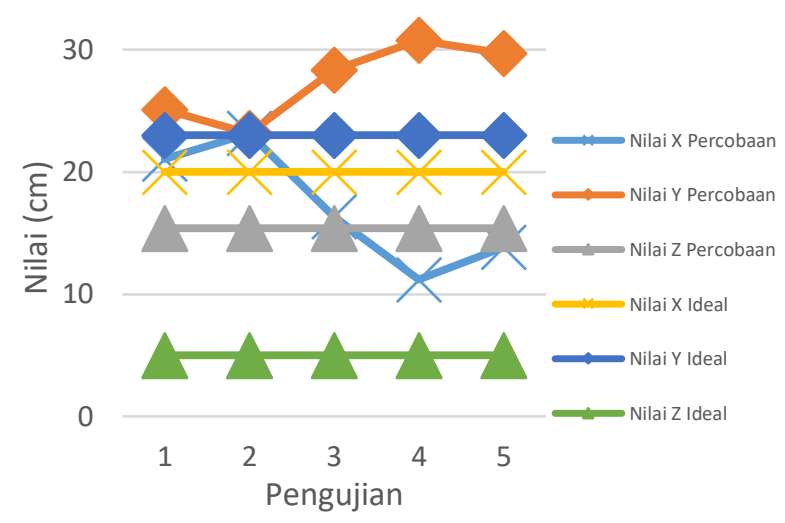

Gambar 16. Grafik Perbandingan Pengambilan Posisi 9

Berdasarkan Gambar 16, rata - rata error pada pengambilan posisi 9 sebesar $X=4,55 \mathrm{~cm}, Y=4,39 \mathrm{~cm}$ dan $Z=10,3895 \mathrm{~cm}$. Error $X$ dan $Y$ terbesar terjadi pada pengujian ke-4 dengan nilai error berurutan $8,805 \mathrm{~cm}$ dan $7,75 \mathrm{~cm}$. Error $\mathrm{Z}$ terbesar terjadi pada pengujian keseluruhan dengan nilai error $10,3895 \mathrm{~cm}$.

\subsubsection{Pengujian Pengambilan Posisi 10}

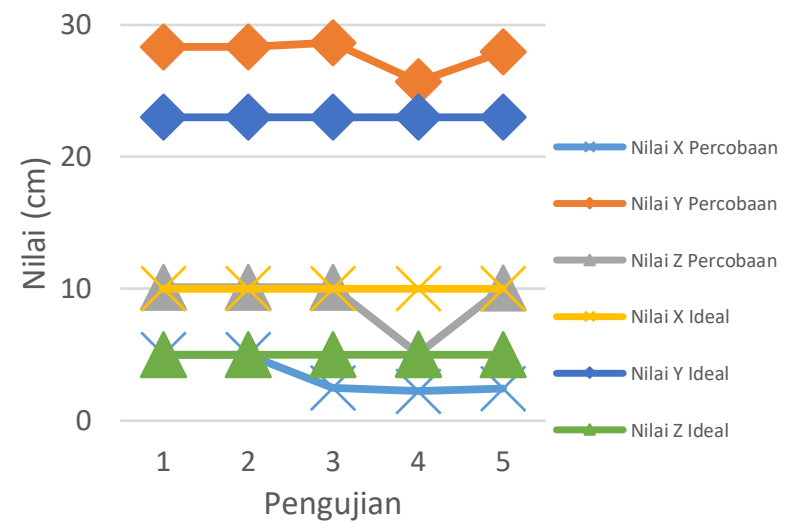

Gambar 17. Grafik Perbandingan Pengambilan Posisi 10

Berdasarkan Gambar 17, rata - rata error pada pengambilan posisi 10 sebesar $X=6,56 \mathrm{~cm}, Y=4,79 \mathrm{~cm}$ dan $Z=4,1 \mathrm{~cm}$. Error $X$ terbesar terjadi pada pengujian ke4 dengan nilai error $7,75 \mathrm{~cm}$. Error Y terbesar terjadi pada pengujian ke-3 dengan nilai error 5,66 cm. Error $Z$ terbesar terjadi pada pengujian ke-1, ke-2 dan ke-3 dengan nilai error $5,12 \mathrm{~cm}$. 


\subsection{Pengujian Sistem Keseluruhan}

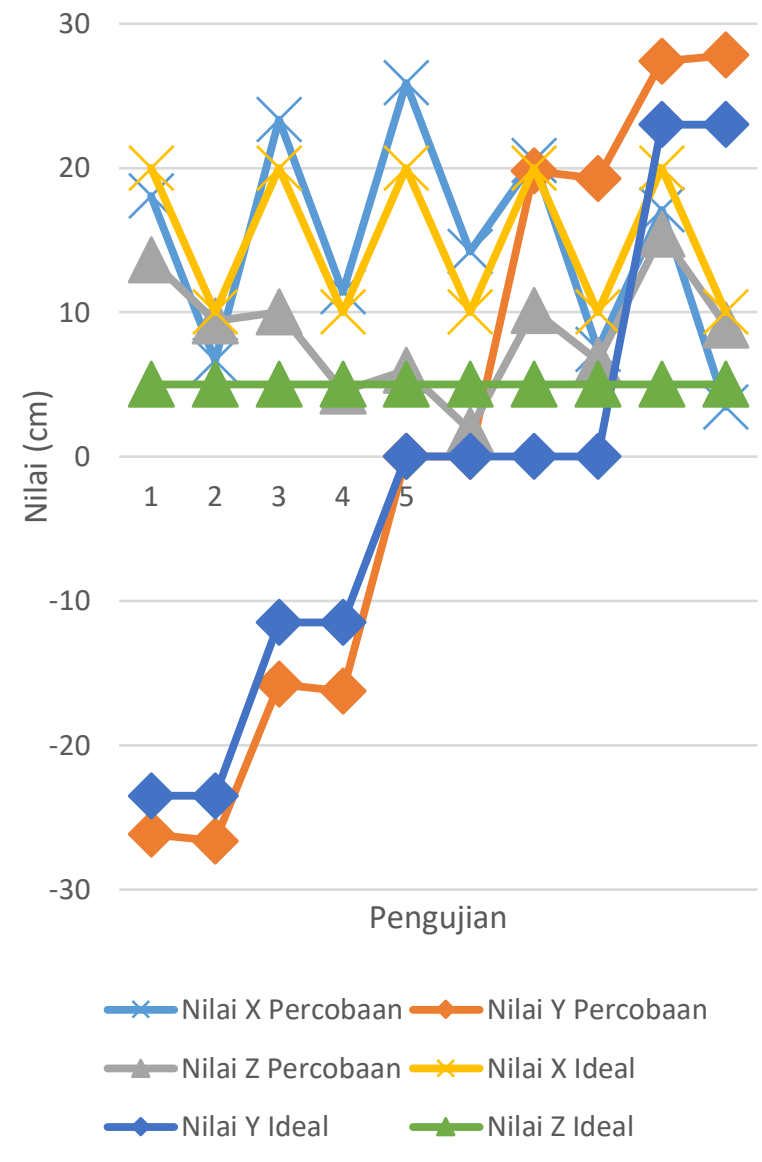

Gambar 18 Grafik Perbandingan Peletakan Barang

Berdasarkan hasil pengujian pada Gambar 18 sistem secara keseluruhan arm manipulator berhasil memindahkan benda. Arm manipulator berhasil memindahkan benda sebanyak 5 kali dengan rata-rata error pemindahan pada sumbu X sebesar 3,6 cm, sumbu Y sebesar 4,17 cm dan sumbu $\mathrm{Z}$ sebesar $4,48 \mathrm{~cm}$.

Nilai pemindahan tersebut masih dapat ditoleransi dikarenakan replika dari barang yang terozonisasi merupakan sayuran atau hasil pangan yang memiliki luas cakupan area diatas nilai error tersebut. Error ini terjadi pada proses servo mengubah nilai pulsa terkirim oleh mikrokontroler, terdapat beberapa batasan perubahan yang dapat diproses oleh kemampuan dari servo. Untuk servo yang terjual sulit untuk memperoleh servo dengan tingkat presisi seperti pada datasheet. Pemanfaatan arm manipulator sendiri sebagai pemindah barang terozonisasi sehingga titik yang tercakup oleh area semprot ozon sprayer telah meliputi dari nilai error yang telah terhitung.

\section{Kesimpulan}

Berdasarkan pengujian dan analisis yang telah dilakukan, maka dapat disimpulkan beberapa untuk sistem pergerakan arm manipulator berbasis algoritma Finite State Machine berhasil dirancang, dengan dapat memindahkan benda ke 10 posisi koordinat yang berbeda. Pada pengujian servo, motor servo Tower Pro MG995 memiliki respon gerak sebesar $9,5117^{\circ}$ setiap $0,1 \mathrm{~ms}$, motor servo RDS3115 memiliki respon gerak sebesar $13,13^{\circ}$ setiap $0,1 \mathrm{~ms}$ dan motor servo RDS3135 memiliki respon gerak sebesar $13,344^{\circ}$ setiap $0,1 \mathrm{~ms}$. Terdapat perbedaan antara perhitungan dan pengukuran sinyal PWM dari mikrokontroler diperoleh rata-rata error sebesar 0,007 ms dan error dutycycle sebesar 0,02 .

Pada pengujian pergerakan secara keseluruhan, arm manipulator berhasil memindahkan replika benda terozonisasi sebanyak 5 kali tiap posisi dengan rata-rata error pemindahan pada sumbu X sebesar 3,6 cm, sumbu Y sebesar $4,17 \mathrm{~cm}$ dan sumbu $Z$ sebesar $4,48 \mathrm{~cm}$. Nilai tersebut telah memenuhi area lingkup penyemprotan ozon terlarut..

\section{Referensi}

[1]. M. F. Faris, A. Triwiyatno, and I. Setiawan, "Perancangan Arm Manipulator 4 Dof Dengan Menggunakan Pengendalian Cartesian Space-Trajectory Planning," Transient, vol. 1, pp. 151-158, 2012.

[2]. M. F. Rahadian, A. Suyatno, and S. Maharani, "Penerapan Metode Finite State Machine Pada Game ' the Relationship ," J. Inform. Mulawarman, vol. 11, no. 1, pp. 14-22, 2016.

[3]. Balai Penelitian Tanaman Sayuran, "Teknologi Ozonisasi untuk Mencuci Sayuran," Iptek Hortik., no. 10, pp. 1013, 2014

[4]. Munadi, "Analisa Forward Kinematic Pada Simulator Arm Robot 5 Dof Yang Mengintegrasikan Mikrokontroler Arduino-Uno Dan Labview," Rotasi “Jurnal Tek. Mesin," no. VOLUME 15, NOMOR 2, APRIL 2013, pp. 37-43, 2013.

[5]. I. Setiawan, "Perancangan Software Embedded System Berbasis Fsm,” pp. 1-2, 2006.

[6]. D. Sawicz, "HOBBY SERVO FUNDAMENTALS."

[7]. ATMEL, "ATmega328/P DATASHEET," 2016.

[8]. XLSEMI, "XL4015 DATASHEET 